\title{
Institutions as Tools of Public Policy: A Comparative Evaluation of South East Asian-Sub-Saharan African Post War Development
}

\author{
Munetsi Mandere \\ Nottingham Trent University, Graduate School, Clifton Campus, Nottingham NG11 8NS, UK
}

\begin{abstract}
In general, it can be argued that institutional framework a country or region designs plays a significant role in crafting, applying or even success of public policy. Drawing lessons from how Asia exploited the developmental state's concept by designing institutions which targeted key public policy areas such as education, health, domestic savings, and rural development, or aligned infrastructures such as roads, transport and ports, to drive economic development. The paper explores how this approach can be applied in sub-Saharan Africa (or individual countries). The objective is to extricate constant factors impacting development both in ahistorical and atemporal terms. The investigation is guided by the key question: whether quality of institutions and institutional analysis can help explain development failures in Africa? Hence, on one part, it probes institutions, institution-making, public policy making and what uniquely the Asian developmental state did that can help illuminate institutional role in policymaking and application. In pursuing this objective, the paper is cognisant of the question by Brousseau et al. asked, regarding generalizability of institutional capabilities, "If growth-enhancing institutions are identified in a specific country, can other countries learn from and transplant these". The investigation concludes that in public policy and development strategy-making institutions do matter as they delimit or even help create possibilities necessary for development and its sustenance, and to a certain extent, they are the vital constant (factors) that explains development differentiations in different geographic spaces or time periods.
\end{abstract}

Key words: Development, developmental state, institutions, IO (international organisations), public policy, SEA (South East Asia), SSA (Sub-Saharan Africa).

\section{Introduction}

It has been argued that institutional framework that a country or region develops has a large bearing on the quality of and the application of public policy and hence on the development outcome $[2,4]$. Drawing on the lessons from the Asian developmental state articulation of institutions to craft unique development approach, this article probes Sub-Saharan Africa difficult development in the post-war period, through evaluation of its contemporary experiences. Methodologically, this exercise is a desk literature

Corresponding author: Munetsi Mandere, Ph.D., postgraduate researcher, research fields: institutions, international system and power, development studies, critical development approach, developmental state and development in Africa, development economics, globalisation, hegemony and the third world and concept of international society, citizenship and justice. E-mail:munetsi.mandere@my.ntu.ac.uk ormunetsima@yahoo.com. analysis of institutions and institutional analysis drawing largely from [5, 6] and Public Policy evaluation as highlighted by Lasswell [7, 8]. Using these frameworks to explore policymaking, policymakers and policy application, the research comparatively assesses how the Asian developmental state manipulated institutions to formulate and implement public policy and to what effect they will take. It will then compare this with Sub-Saharan African progress relative to institution-driven policymaking and application. The paper concludes by noting as Habtamu [9] argues that institutions are central to policymaking and hence the quality of institutions and skills (authority) of policymakers have a large bearing to a country, regional or international development and its sustainability as witnessed in SEA example. 
In the first part, the paper explores understanding of institutions and application drawing largely arguments from Oliver Williamson [5] and institutional analysis from Keohane [10] and Eggertsson [6]. Speaking of the origins of institutions, Keohane [10] highlights that analysing world politics in the 1990s literary meant probing international institutions understood as "the rules that govern elements of world politics and the organisations that help implement those rules" [10]. This observation is a key understanding of what institutions are in this enquiry and what their objectives are. Oliver Williamson [5], on the other hand, emphasises the distinction between normative and empirical analysis of institutions. He underscores difference between what he terms institutional environment (of institutions) which underscored aspects centred on the political and legal rules that guide institution-making and as he noted, is more macro-analytic in emphasis as compared to the governance institutions that are more micro-analytic in their dealing with markets and firms [5].

In the second part, a review of conditions impacting and role of actors involved in policymaking drawing inspiration from the Harold Lasswell's [7, 8] framework is made. The article then comparatively evaluates the Asian developmental state articulation of institutions emphasising the normative environmental framework and the key actors in the process which all have a bearing on the resultant institutions and the practical policy application outcome. This is compared to sub-Saharan African development condition cognisant of dangers of generalisation pitfalls (as hypothesised by Brousseau et al. [1]) above before drawing reflective conclusions from the observations made.

In terms of relevance and limitation, it will be appreciated that the paper is a literature-based evaluation of institutions, institutional analysis and their effect on public policy-hence is non-empirical. In addition, the time period under review is overly wide (post-war to present), the data analysed are not recent as to make some illustrations out of sync with current realities. In essence, it is an exploration of what institutions are, can do and outcome, rather than how and what specific institutions are crafted and by whom. Whatever the case, the paper is relevant as it highlights some unresolved tensions between the realist institutional purview of purported actor competition for relative power against the idealist cooperative absolute power quest notions in international relations and governance systems relative to objectives of the international system. Part of the intrigue is that when institutions are viewed from a realist perspective they mediate different objectives and outcomes to those of idealists or institution a lists where the former emphasises power, relative gains and self-interests and the later underscore cooperation and mutual interests. In the end, the exact premise why institutions are essential to international relations and governance is an area which needs continued study rendering this illuminative piece relevant to the extent of keeping the debate ongoing and not so much about its conclusions.

\section{Broad Understanding of Institutions and Key Objectives}

Eggertsson argues that when social structures and social systems yield expected and desirable results, there is virtually no need for institutions, and institutional analysis is handy in times of change and transformation [6]. Eggertsson further noted that institutional economic analysis rose to prominence in the 1980s when it focused on economic and social organisation in an era of great change as the Soviet Empire disintegrated [6]. Hence, one key way of understanding role of institutions is the centrality of change (and possibly uncertainty) and transformation possibly in the context of game theoretic dilemmaand agony in the face of unknown (uncertain) outcomes of bargaining. However understanding and evaluating institutions is not so straight forward [11, 12], and as Keohane point out, in early post-war years around the 
1960s, American International Relations students regarded international institutions as the same with IOs (International Organisations) such as the United Nations, the EU or Africa Union [10]. So, understanding what institutions are is problematic, but here as explained by Polski and Ostrom, North, Siba, institutions are taken as "rules, norms or strategies that create incentives for certain behaviour in repetitive situations" [13-15].

Polski and Ostrom (1999) also draw distinctions between an institution and an organisation, pointing out that organisation was a "set of institutional arrangements or participants who have common goals and purposes and who interact in multiple actions in various situations" [13]. North, on the other hand, defines institutions as "humanly defined constraints that structure political, economic and social interaction". He adds that this consist of both informal constraints such as sanctions, taboos, customs, traditions and codes of conduct as well as the formal rules such as constitutions, laws and property rights [14]. These institutions as North adds have been devised by human beings throughout history to create order and reduce uncertainty in various exchanges. Equally, Torrance underscores the distinction between economic, political and cultural institutions and the impact they make to economic and social development. Here she highlights that economic institutions are necessary when their costs are less than the benefits emanating from institutional application. On the other hand, political institutions arise out of need for redistribution of resources rather than efficient manipulation while cultural institutions, though hard to characterised, Torrance adds that these are more of informal beliefs that inform collective action or system of governance tend to be context specific [12].

Underscoring the foundational premise of institution-making, on one hand, realists firmly argue that International Relations is solely about states quest for power and self-interests but this is refuted liberal intuitionalists. Institutionalists on another contest this, as highlighted by Devitt that, "the world should be imagined as a place where actors other than states play significant roles in world politics, without hierarch zing issues of priority and in which force in not an effective instrument of policy" [16]. Devitt like underscoring the essence of cooperation based on common values and expected mutual benefits hence asserting that states and non-state actors submit to common rules and institutions for mutual outcomes. The dividend of this cooperation, emanating from the complex interdependences as Devitt highlights is the creation of integrated communities that promote peace and economic growth. In practice, he adds the approach (institutionalism) emphasises soft power, cooperation, application of forms of international law, diplomacy and general international organisation [16].

However the notion of institutions as autonomous, independent and even alternative approach to realist notions is criticised by theorist such as Mearsheimer quoted by Andreev who observes that International Organisations (IO) (as key players in institution-making) are set-up by states (a creation of states) and are dependent on them and act for their interests especially security issues. Hence, he added that institutions were effectively a reflection of the distribution of power in the world, based on rational self-interest calculations and has no independent effect on state behavior [18]. These realist notions are vehemently refuted by institutionalists who argue that institutions (key role of institutions) alter state influence and hence change its behaviour. By doing so, they added institutions discourage calculation of self-interests on the basis of trying to achieve relative power. Effectively, as institutionalists argue, international organisations function as arenas or forms of interstate policy cooperation premised on the view that states are not the only actors in international affairs and that security is not the main focus of attention in this arena. They argue that cooperation among states and non-state actors is the product of IOs 
action along with international regimes, agreements and norms [18].

On the other hand, Thakur and Weiss highlight the weakness of the institutionalist approach if analysed through principal-agent theory perspective. As they explain, Principal-Agent theory emphasises the ability of the principal to sanction an agent by changing the contract (dismissing or not extending agent contract, changing terms of the contract, reducing authority, cutting budget etc.), which provides states with significant leverage it can use to control agents who go astray [19].

Mitchell, on the other hand, points out that both institutionalists and rationalists treat state preferences as fixed and the role of International Organisation membership as necessary to influence interstate bargaining for absolute power [20]. In Mitchell's view, IOs act either as constraints by compelling states to negotiate efficiently (with less costs and more information) without changing much their preferences. On the other hand, from a constructivist view, states' long, deep and sustained interaction with International Organisations can have constitutive effects on members' preferences and behaviour (or interests and identities)- hence in this view preferences are not fixed [20].

Analysing (institutional) application, Williamson, argued that new institutional economics was constituted of two parts where one aspect dealt with the conditions (environment) underpinning the exercise and the other with the actual mechanism and the application [5]. He adds that the former is a general framework that influences the direction to be taken while the latter is a specific function that involves the exact dos and don'ts. These inter-related parts as further explained by Davis and North cited by Williamson emphasise that on one part institutional environment was a set of key political, social and legal ground rules that guided production, exchange and distribution processes. On the other, institutional arrangement was an orderly arrangement between economic units that governed how the actors cooperate or compete [5].

However, Keohane argued that to understand conditions under which international cooperation takes place, it was necessary to probe how institutions worked and factors affecting how they come to being - the so-called source and nature of institutions [21]. He situates his analysis of institutions and key actors in what he termed complex interdependence of states in an anarchical world. In this view international institutions were implemented by International Organisations (read as actors seconded by states) which included international regimes that were more informal and more of norms at the same time [10]. According to Keohane, analysis of international cooperation in the $1980 \mathrm{~s}$ escalated from merely explaining interdependence and international regimes to include closer review of the conditions under which countries cooperated. What was intriguing political scientist then was the apparent contradiction between the realist purview of the motivations of a state-power, selfish self-interests and optimisation of possible gains (underpinned by relative power and zero-sum game).

However Keohane notes the difficulties faced when institutions were taken as superior to the state-given the concept of state sovereignty. He admits that institutions were seen as devices crafted to help states achieve their objectives within the realist framework then this made sense [10]. In practice, Keohane postulated that institutions create conditions for cooperation in mutually beneficial ways by reducing transaction costs of making and enforcing agreements. Importantly, Keohane observed that since international relations operate in a game-theoretic condition characterised by uncertainty and brinkmanship, actors do not engage in centralised enforcement of agreements, but underscore practices of reciprocity by providing incentives for states to keep their commitments to attain mutual benefits [10].

Furthermore, Keohane intimates that at one level, if institution-making and application is taken in the 
context of relative gains and self-interests then it is decidedly a rationalist enterprise, or more specifically as he adds drawing from Herbert Simon [22], it was a substantive rationality. Substantive rationality implied a situation where actors sought optimal outcomes by constantly adapting to obtaining condition, hence outcome would be context specific [21]. However, from a sociological point of view, as Keohane observes, study of institutions underscores influence of impersonal social forces such as cultural practices, norms, and values that are not derived from interest calculation. Effectively, Keohane recognised that institution-making in this context was the product of these social forces, individuals, local organisations and even states. On this basis, institutions do not only reflect preferences and power of components constituting them, but the institutions themselves impact the preferences and level of power derived from the process [21]. In short, as Keohane emphasises, institutions are constitutive of actors and actors are constitutive of institutions. In addition to the discussions above and throughout this paper, institutions in general will be taken as reflected by Keohane as a general pattern or category of activity or a particular human-constructed arrangement, formally or informally organised and in particular as complexes of rules and norms identifiable in time and space [21].

Alternatively as reflected above, Williamson viewed institutional analysis from two fronts-the general normative institutional environment and the specific institutional governance arrangements. $\mathrm{He}$ argues that institutions matter and needed analysis and that private ordering and de facto organisation against (de jure) legalistic enforcement in economic action needed closer attention too [5]. Citing Davis and North, Williamson explained that institutional environment was a set of political, social and legal rules that guide production, exchange and distribution. However, institutional governance was an arrangement between economic units that controlled how these units cooperated or competed [5]. In addition to the two approaches to institutional analysis, Williamson adds that the individual actors were also relevant point of enquiry. The individual's role in institution making comes in the context as posited by Simon, cited by Williamson in transaction costs analysis that human cognition is subject to bounded rationality in which actor behaviour is defined as intendedly rational but only limitedly so [5].

Assessing policy analysis and application, professor Montpetit noted that this depends on the approach of the chosen public policy-either from a narrow or broader view. He adds that a narrow view pertains to governmental actions where analysis is focused on characteristics and impact of these actions and the process is general normative as it is limited to advising policymakers. On the other hand, if the view is broader, Montpetit observes, the analysis often is explanatory in nature and is not concerned with improving the quality of the programme, but to investigate how (and maybe why) polices are developed and implemented [24]. In view of this clarification, in this paper policy is taken as defined by Dukeshire and Thurlow, who intimated that a policy is a declaration that defines the intention of a community, organisation or government's goals and priorities by outlining the roles, the rules and the procedures [25].

As part of this research is to explore to what extent institutions impact public policymaking and application, it is therefore logical to unpack the meaning, objectives, and conditions underpinning the process. Bogason intimates that arguments abound in policy literatures that emphasise that policymaking is centrally concerned with authority, expertise and order [26]. The literature $[26,27]$ underscore that the key actors of policymaking are normally governments though not the only ones, who initiate authority relations to underpin policy propositions and principles to ensure that these are implemented. He adds that the principles are sourced or derived from certain knowledge banks (expertise) of the areas policy is directed at. Ultimately the policy framework 
is aimed at solving given problems within the target area hence ensuring order in society and progress of some shape or foam [26, 27]. In simplistic terms, as Bogason adds, Policy is created, decided upon, the good and the bad alternatives assessed, implemented step by step by collecting information, and ultimately deciding on the optimal course of action that produces the best outcome at the lowest cost [26].

As Bogason further explains, policymaking comes from several approaches although the rational approach dominates the so-called sequential policy-making models popular in constitution-making (where emphasizes on separation of the political from the administrative), managers and management consultants. The approach is top-down in that experts at the apex of an organisation design the package that achieves desired goals [26]. In the same vein, Rao quotes several authorities in policymaking including David Easton who defines public policy as the authoritative allocation of values for the whole society [27].

On the other hand, Rao cited Lasswell and Kaplan [42] who characterised public policy as a projected programme of goals, values and practices while Thomas R. Dye [28] regarded it as whatever governments choose to do or not do. From all this Rao observes, a position the author also agrees with, that the fact a government chooses to do (or not do) something means there is a goal, an objective and a purpose [27]. In addition, public policy comes in various forms, regulative, organisational, distributive, extractive and supportive [19, 27].

Equally, as Rao [27] further observes, public policy defines government relationship with its citizens and non-state actors. Therefore in this context, acceptance of a government by individuals or groups gives the government authority to act as well as conferring it with legitimacy and approval. As an action programme, Thakur and Weiss add that policy is not just the governing principle, but includes decisions to embark on certain programmes of action (or inaction), to achieve certain goals. The need for action is premised on perceived problems that need resolving [19].

However, according to the Lasswell, framework, policymaking follows certain presumptions, a problem and the need for change or transformation one way or the other. $\mathrm{He}$ added that the key to managing or initiating this change follows what he called five intellectual maps/tasks: the goal, trend, condition, projection and alternatives [8]. Lasswell points out that each policy cycle broadly follows this guideline. In the Goal realm he explains, the task is to explore what need to be realised (or achieved) by the social interaction; Trend realm hypothesises what extent the past or recent events reflect the expected endpoint; Condition analysis explores what factors affected direction and depth of current and past events; Projection of developments questions whether needed goals are achievable or how far-off target position is reached if current policies are continued; Invention, Evaluation and Alternatives stage, questions what strategies and interventions can ensure realisation of preferred goals [8].

Acknowledging robustness of above, as noted by Professor Montpetit, the Lasswell framework effectively, though not universally accepted inscribe the following stages: agenda-setting, policy formulation, decision making, policy implementation, and policy evaluation [24]. However, Lasswell (1971) emphasises that his framework was both a guide on policy content and a procedure, in which as content it directs what questions to ask relative to problem at hand while as procedure, it advises on wisdom of structured and orderly articulation of policymaking and application processes [8]. Critically, Lasswell emphasized that the principles of this framework cautioned that goals are held as tentative until subjected to exposure through other stages of the process and even so, the exercise should be continuously repeated and refined to achieve higher outcomes [8]. 
While accepting the enormous contribution of the Lasswell [8] framework, it must be highlighted though that this was not without controversy, with several analysts $[29,30]$ questioning the claim that the framework synthesised the scientific based study of a problem and policy-making actions around this problem. As Turnbull [29] highlights, Lasswell [8] drew fundamentally from Dewey thought in which it was argued that knowledge as a form of experience resolved problems. In the research programme (by Dewey and Lasswell) cited by Turnbull [29] a problem was defined as "the discrepancy between goals and the actual or intended state of affairs" [29]. Turnbull argued that Lasswell formalised his vision of policy science by exploring what he (Lasswell) regarded as two orientations of policy. In that study, Turnbull [29] contends, Lasswell explored from a sociological and psychological perspective the "science of policy formation and execution" on one side and then evaluating the "content of (policy) information and interpretation available to policymakers on the other" [29].

However, Lasswell clarified his thinking by alluding that policy sciences were concerned with knowledge of and (knowledge) in decision-making process on public and civic order where knowledge of decisions is a product of "systematic, empirical studies on how policies are made, (by who) and to what effect". On the other hand, he added knowledge in decision-making draws from "various scientific disciplines to increase stock of knowledge relevant to public policy". Clearly as he observed, there was a normative policy conception and analysis from various sources and a policy application and explanation on the other. However, Turnbull emphatically insisted that the theoretical relationship of Lasswell two poles (aspects) of policy above was not scientific [29]. Bobrow et al. curtly intone that it was a fallacy to try and extricate "policy aspect" from the wider Political Science discipline and research agenda [30]. The details of this dispute is beyond the objective of this paper suffice to the say the Lasswell policy science claims are contentious though his policymaking and application framework is generally accepted as seminal.

\section{The Asian Tigers: What Did They Do Right?}

In the opening remarks, the question partly informing this paper as borrowed from Brousseau and Raynaud [1] was highlighted in they which ask "If growth-enhancing institutions are identified in a specific country (or region), can other countries learn from and transplant these?"[1]. In the same vein and reflecting on the Asian economic miracle, Easterly observes, and quite rightly too, that the success story of the Tigers was tantalising, hence obviating questions whether this could be understood and possibly replicated in other poor countries to resolve world development problems? [31]. To partly address these questions, the author asks as many analysts do, what did the Tigers do that can possibly be emulated albeit with situational and temporal modifications. The paper does so by exploring possible constant factors and conditions that explain the relation between policy and growth by suggesting institutions (and organisations the product of and working with institutions) and institutional analysis could help explain these miracles, also bearing in mind dangers of unwarranted generalisation.

According to van Donge et al., the Asia consistent development was driven by amongst other things by policies (who makes policies?) focusing on macroeconomic stabilisation; improving rural life; increasing agricultural productivity and ensuring sufficient food supply; liberalising the economy and guaranteeing condition for economic freedom especially for peasant farmers and other smaller sectors [32]. The three key pillars of this approach were the creation of robust structures that ensured macroeconomic stability, rural and agricultural economic development and economic liberalisation. 
As will be reflected later, the key to success of the development strategies here was among other things high level of bureaucratic expertise, total empowerment and protection against all forms of interference [33]. Uniquely and as part of the defining characteristics the Asian States, they took it upon themselves to create robust rules, laws and policies (read as institutions) that guaranteed bureaucratic freedom and support in implementing technocratic decisions without fear or favour, hence the key role of institutions. In a way the protected role of bureaucrats, empowerment to make decision and applying resolutions without interferences also underscores the important role of institution-making as aligned to subsequent rules which are the product of technocratic actions.

Alternatively, as Hans Loof explains, in the case of the Asian Tigers (essentially Hong Kong, Indonesia, Taiwan and South Korea) the state was a key player in the turn-around by directly crafting certain institutional arrangements. Here Loof adds, the state allocated sufficient resources to key industries, built essential infrastructure to support the key areas and redoubled support for educational system [34]. Further, the state introduced a rigorous welfare public spending in which on one end it encourages domestic savings by everyone (state, corporations and households) and on another provided incentives for innovation and enterprise. The outcomes were double pronged in that higher rates of education were achieved as well as abundance of cheap labour which all drove productivity up [33, 34].

On the other hand, Roemer locates in part one source for this growth (Tigers Economy) on sheer accumulation of the factors of production' quoting Young [36] as concluding that growth in per capita income for the four Asian tigers could be explained by factor accumulation including physical and human capital and the attendant increase in worker numbers [35]. Factor productivity was explained as the unexplained residual productivity.

Viewed at this way, Roemer hypothesises that if
East Asian growth could be explained through total factor production, rise in income per capita and increased worker numbers, then Africa needed to inculcate policies that; induce higher saving (efficiency) and invest in equipment, infrastructure and education in order to accelerate growth. He added that efficiency context included requirement for balanced budgets (or even surplus budgets); reform of government expenditure, introduction of higher interest rate for savers, possibly subsidise rates for borrowers, introduce higher taxes on consumption and introduce mandatory (my emphasis) savings schemes. These policy options, Roemer felt were constant factors that potentially drove growth regardless of locality and time period.

Another key development driver cited by Roemer was political stability driven surprisingly by long political stewardships of certain leaders during the transition [35]. However, it was observed that political stability alone without other factors was not sufficient to stimulate growth. For example, he noted Africa has recorded long periods of the same leaders but without any noticeable development dividends [35]. Roemer adds that there must be desire by political leaders to trade off political capital through certain government policies to achieve sustained growth. For example as he noted, South East Asian leadership appeared to focus on long-term development rather than short term political and personal gain. Roemer also observed that although in both regions rent-seeking was common, most south Asian countries barring Philippines realised that sustained rents required growing economies hence sacrificed these when they impacted on economic performance. However on the contrary, Roemer [35] argues that African leaders extracted rent without due regard to economic growth and hence this effectively declined. In addition, Roemer [35] highlights that tolerance and inclusive polices that protected the entrepreneurial ethic Chinese minorities played a big role in industrial and commercial turnaround in Indonesia, Malaysia and Thailand. This, 
as observed added to the policy of protecting economic progress from politics which ensured sustained development. In contrasts, Roemer explains Africa was intolerant of for example Lebanese in West Africa, ethnic Indians in East Africa and even minority indigenous people were not protected with obvious negative results.

However, Ursula Oberst noted, that the following key policy interventions drove the Tigers Economic turnaround; the Principle of Outreach which emphasized quantity NOT quality. Oberst underscores while summarising a Tracking Development Conference deliberations in Malaysia in May 2010: (a) that in (all) successful developmental states, the primary criteria on which policies and interventions are selected should be the numbers of people to whom they provide direct (measureable) material benefit. (b) The principle of "Urgency" which emphasized priorities NOT (good) plans. Here he adds that at minimum, at the beginning of the development process, successful strategies do NOT involve meticulous long-term planning based on predicted and desirable future. Rather, they involve establishing clear priorities based on what is desirable at present. (c) The principle of Expediency emphasising the results and NOT the rules. Oberst highlights that this observes that in successful developmental states, legal principles, administrative procedures, political rights, and ideological requirements all take second place to the goals of improving the material living conditions of as many people as possible and as quickly as possible. In practice achieving these goals may mean tolerating corruption, bending rules and infringing certain rights [37].

Overall various analysts have given multiple observations as underpinning the Asian Tigers development model which could possibly be emulated by Sub-Saharan Africa albeit with modifications to suit conditions, global changes and other factors. The textboxes below summaries what Asia did as compared to Sub-Saharan Africa.
Over and above the factors raised above, it is agreed that in general the Tigers variously promoted friendly land tenure (use) systems that guaranteed property rights and assured agricultural workers long-term security. The particular land reform highlighted by Loof, included aspects of subsidies and tariff on some agricultural products designed to drive agricultural productivity and food security. Loof says emphatically that the key drivers of the Asian Tigers turnaround was underpinned by forms of state participation in the economy, fundamental educational and land reforms, agricultural promotion, sustained export strategies, promotion of foreign direct investment underpinned by stability and promotion of high domestic savings [34]. He also underscores that the Tigers, though broadly following similar strategies were underpinned by different comparable advantages: Singapore and Hong-Kong largely exploited their vast seaports and aligned ship building processes while South Korea and Taiwan leveraged cheap but highly skilled labour to manufacture high value export goods or higher quality services [34].

It was also noted that though the Asian Tigers benefitted significantly from foreign aid and foreign direct investment, as Booth pointed out these contributions were possible because of the policy of "insulated bureaucracy" and economic freedom. Here the highly skilled experts where shielded from political, powerful interests groups or corporate interference to allow them to pursue results based programmes on key areas [33]. As highlighted, this protection of bureaucrats had the added effect of reducing corruption and other rent-seeking actions.

Interestingly and maybe requiring further probing, many development analysts [9, 32] noted that both regions (SSA and SEA) were formerly occupied by colonial powers who left various economic, cultural and educational legacies but absence of basic rights, accountability, political stability (normally associated with democracy) and corruption had no bearing on 
Table 1 Snapshot of interventions and policy action applied by SEA which helped their development.

\begin{tabular}{|c|c|}
\hline Analyst/Author & Key requirements \\
\hline Roemer [35] & $\begin{array}{l}\text { - Roemer contends in a nutshell that these are the areas or actions that SSA should focus on as learning from } \\
\text { - South East Asia experience. } \\
\text { political support. } \\
\text { - Create Environment where all ethnic groups especially the talented and gifted can participate with } \\
\text { minimum risk. } \\
\text { - Design Strategies that hinge on existing comparative advantage including agriculture and labour intensive } \\
\text { industries. } \\
\text { - Invest in education that will create sufficient skilled workforce to will sustain new industries and service } \\
\text { export market. } \\
\text { - Adhere rigorously to sound macroeconomic policies including adoption of flexible exchange rates, } \\
\text { maintain small budget deficits or even balanced or surplus budget and tight monetary policies including } \\
\text { currency convertibility. } \\
\text { - Ensure flexible labour markets where wages, employments and conditions are controlled by markets } \\
\text { (hiring and dismissals without government interference). } \\
\text { - Reform financial markets to ensure market forces determine credit allocations, interests rates, currency } \\
\text { convertibility rates by so doing creating a good investment climate. } \\
\text { Conduct trade reforms to liberalise economies and open them to world markets while leaving a certain } \\
\text { level of protection and facilitating acquisition of input material and equipment to export producers duty } \\
\text { free and without import controls. }\end{array}$ \\
\hline $\begin{array}{l}\text { Sachs Jeffrey D, } \\
\text { Finance and } \\
\text { Development [38] }\end{array}$ & 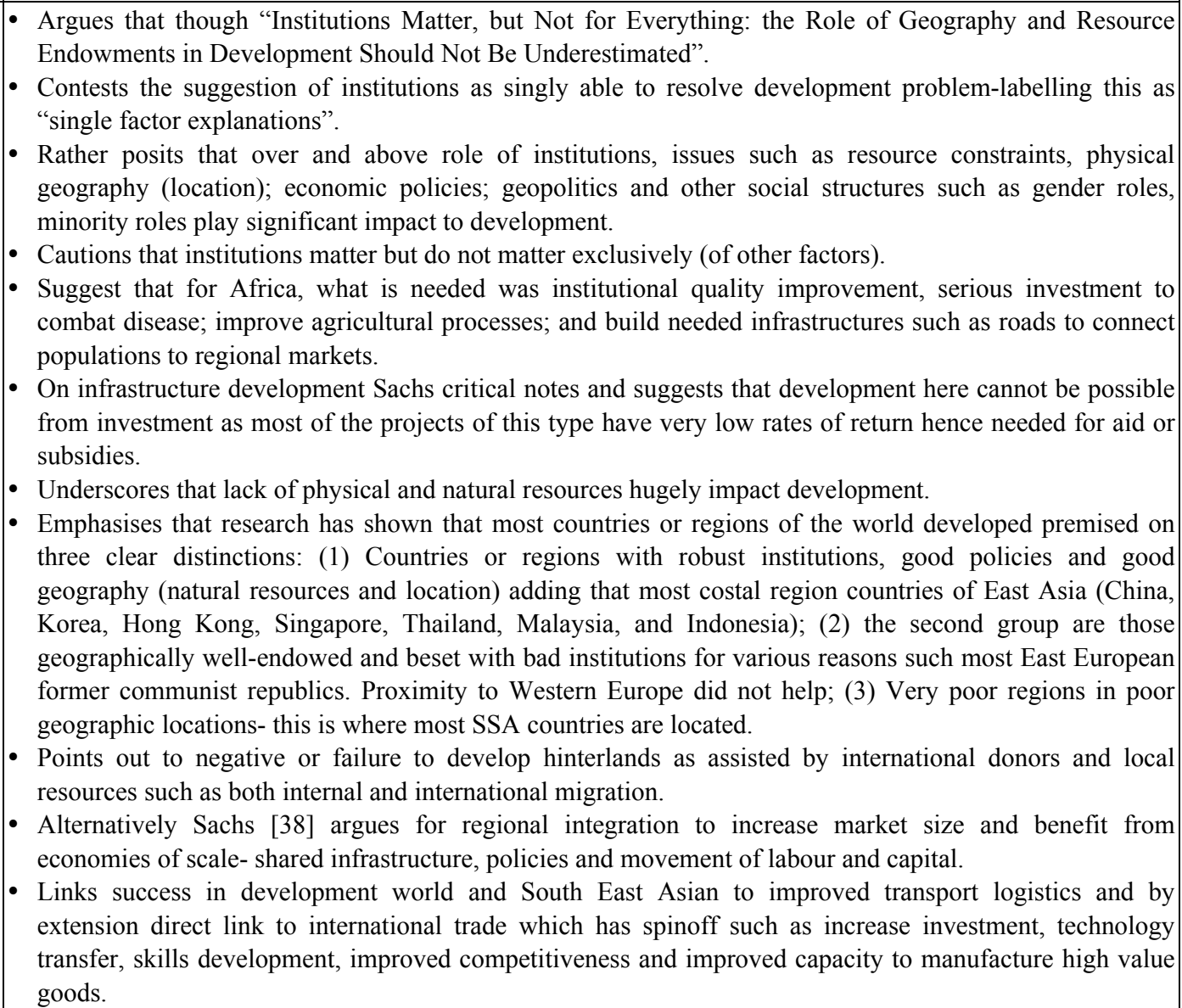 \\
\hline
\end{tabular}


growth [9, 32]. They found that both regions were notorious intolerant of opposition and corruption endemic though one region progressed while the other regressed under these conditions.

\section{Sub-Saharan Africa: What Is the State of Institutions and Policies?}

Van Donge [32] noted that despite current growth patterns, Africa has failed to attract sufficient foreign direct investment except in extractive industries and tourism sectors. He, like many other analysts (e.g. Habtamu) [9] attributed this failure variously at governance and polity as failing to create a conducive environment [32]. While steadfastly locating the African developmental problem squarely in institution-making and quality, Van Donge [32] and Habtamu [9] also noted interesting similarities and difference in the Africa and Asian situations. Van Donge observed that corruption though endemic in both regions; the origins were different though the effects were the same. He argued that the Asian corrupt actions were mutual, while the African actions were driven by the big man concept of neo-patrimonialism in which the public-private relations are the patron-client type where politicians, the rich and powerful extract rents for personal satisfaction often at the expense of development [32].

In addition, according to Henley and Van Donge, Sub-Saharan Africa rural development and agricultural support strategies have been poor and erratic and whenever support was give as in the cited Tanzania case (in the 1970s), investment was not accompanied by economic freedom hence intervention failed [39]. Admittedly, Henley and Van Donge observed that Africa had significantly improved on the macro-economic management and economic liberalisation front. However this improvement, in the absence of higher public investment in rural development, the needed breakthrough in rural economies has also failed as compared to SEA [39].

While contending that the picture of African growth was at best mixed with no clear-cut continent specific outcome, Habtamu [9] was emphatic in pointing out that the source of poor development in Africa, what he termed "slow growth and poor aggregate technical efficiency" was bad governance (also read as poor institutionally quality) [9]. In addition, Habtamu reflecting on the North [14] ascribed role of institutions underscored that it was agreed that they do indeed create order and reduce uncertainty but they did not increase much needed efficiency.

Analysis of results of a study by Habtamu [9] and others on implications of institutions in Africa drawing from certain governance variables used by the World Bank and using various statistical models revealed interesting outcomes. In the analysis, Habtamu sought to probe the key determinants of slow development in Africa as compared to other regions. He characterised governance quality in the study as implying; rule of law, control of corruption, guarantees of (citizen) voice and accountability, political stability, government effectiveness and regulatory quality. Importantly, these governance indicators were clusters of sub-areas that related to each other but details are beyond the objective of this paper [9].

From the analysis, Habtamu [9] noted that governance (institutional quality) affected growth and by extrapolation, argued that there appeared a general correlation between governance quality and per capita income as reflected in sample analysis of South Africa, Botswana and Mauritius and compared to the Democratic Republic of Congo in the period under review i.e. 1996-2005 [9]. He adds that the coefficient of governance quality and the listed indicators was high under various specifications and estimation techniques. By the same measure, the study found out that there was no meaningful correlation between corruption and growth and hence concluded that the results supported the hypothesis that Africa's slow growth could be explained in part through poor governance [9]. In the same vein, Bardhan [40], cited 
by Torrance [12] attributed the lack of African development to coordination failure which could not account for the complexities of industrial investment, innovation and financial markets (which occurred in the West) noting that African nationalist historiography was content on blaming neo-colonialism for the failures [12].

\section{Discussing Key Outcomes}

While acknowledging the outcome of shrewd educational policies and skills training for Singapore, the World Bank had this right to say as quoted by the National Committee of Inquiry into Higher Education "the phenomenal development of Singapore has taken place despite lack of resources and absence of a large domestic market. This remarkable success has to been attributed to sensible and effective policies and early attention paid by Singapore to infrastructure and manpower resources" [41]. However, as a common background, most Asian Tigers polities (like their African counterparts) were military dictatorships although virtually all of them have now transformed into thriving democracies e.g. Taiwan, Thailand and South Korea (National Committee of Inquiry into Higher Education). But given this condition, Henley and van Donge [32] observed in both regions under review authoritarian polities were not significant barriers to growth (e.g. Malaysia was a dictatorship for most of its developmental phase). In addition, they noted that foreign aid, corruption, financial liberalisation, privatisation of public utilities or rise of indigenous bourgeoisie was also without much impact. Equally they observed that Industrial Policy did not seem to facilitate any significant growth and instead, massive rural development appeared to help industrialisation. In the same vein, manufacturing sectors appeared to benefit from good macro-economic strategies, guaranteed economic freedoms, adequate infrastructure development and vibrant rural economy [32]. Almost as a bonus, it was also observed that the above improvements also led to political stability, increased private saving and investment, growth of domestic market, abundant cheap and reliable workforce.

Some observers have argued that the key to all this was that Asian Tigers government key policy choices of "shared growth" based on "growth coalitions" that included peasants and small scale entrepreneurs. These prioritised redistribution of income and assets to the poor and rural areas. The state in development here recognised that government and markets were complimentary not alternatives. Hence government intervention approaches included investment, subsidies, supply of public goods, and redistribution of resources (rather regulation). As noted, government rural policy emphasised that providing inputs and rural infrastructures was futile if farmers were not free to grow crops of their choices and sell to highest bidder [39].

\section{Conclusion}

This exercise is literature based on comparative analysis of the impact of institutions in policymaking and application in different development outcomes for Sub-Saharan Africa compared to Asia. The evaluations are made bearing in mind the dangers of unwarranted generalized ability but highlight centrality of institutions as neutral factors that impact public policy effectiveness and hence development. The undertaking also recognises the tension between institutional and policy premises from a realist power-centred approach anchored on relative gains by actors in international cooperation and institutionalism/idealism notions premised on absolute gains motivations which militates and motivates cooperation by the same measure. In the subsequent evaluation, the paper, rather than focus on probing specific institutions and institution-making as the objective of explanation, was content on illustrating and illuminating what institutions potentially can or actually able to do. By so doing, the investigation highlighted possibilities inherent in institutions as 
facilitators (or inhibitors) of public policy and what emerges when they are carefully manipulated. The case for either institutional by-product was exemplified the comparative assessment of differentiated development of SSA and SEA. All what this paper has done in part was to highlight role of institutions in impacting development strategies and what it has not done was to attempt to highlight which institutions are crafted and why. This deeper understanding of specific institution making and their direct relation to specific outcomes both in SEA and SSA is left for another day.

\section{References}

[1] Brousseau, E., Garrouste, P., and Raynaud, E. 2011. "Institutional Changes: Alternative Theories and Consequences for Institutional Design." Journal of Economic Behaviour and Organisation 79: 3-19.

[2] Acemoglu, D., and Robinson, J. A. 2008. "The Role of Institutions in Growth and Development." Commission on Growth and Development. Working Paper, No. 10: $1-44$.

[3] Acemoglu, D., Johnson, S., Robinson, S., and Robinson, J. A., 2005. "Institutions as Fundamental Cause of Long-Run Growth." Handbook of Economic Growth, 1A: 385-472.

[4] Revila-Diaz, J., Schiller, D., and Zvirgzde, D. 2013. "Similarities and Differences of Institutional Change in ENP and Other Catch-up Countries." Press Release. Working Paper no. 5/14: 1-31.

[5] Williamson, O. E. 1995. "The Institutions and Governance of Economic Development and Reform." In Proceedings of the World Bank Annual Conference and Development Economics, 171-96.

[6] Eggertsson, T. 2006. "On the Survival of Imperfect Institutions." Economic Analysis Review 21 (2): 13-24.

[7] Lasswell, H. D. 1970. "The Emerging Conception of the Policy Sciences." Policy Sciences (1): 3-14.

[8] Lasswell, H. D. 1971. Preview of Policy Sciences. Madison, University of Wisconsin: American Elsevier Publishing Co.

[9] Habatamu, F. N. 2014. "Role of Governance in Explaining Economic Growth in Sub-Saharan Africa." Africa Policy Journal 1-21.

[10] Keohane, R. O. 1998. "International Institutions: Can Interdependence Work?" Foreign Policy (110): 82-96

[11] Ostrom, E. 2010. "The Institutional Analysis and Development Framework and the Commons." Cornell Law Review 95 (4): 807-16.
[12] Torrance, S. 2006. "Indigenous Origins of Institutions in Sub-Saharan Africa." CREDIT Research Paper, 13/06: 1-31.

[13] Polski, M. M., and Ostrom, E. 1999. "An Institutional Framework for Policy Analysis and Design.” Indiana University, 1-49.

[14] North, D. C. 1991. "Institutions." Journal of Economic Perspectives 5 (1): 97-112.

[15] Siba, E. G. 2008. "Determinants of Institutional Quality in Sub-Saharan Africa, School of Business, Economics and Law." University of Gothenburg.

[16] Devitt, R. 2011. "Liberal Institutionalism: an Alternative IR Theory or Just Maintaining the Status quo?" University of Melbourne, 1-7.

[17] Mearsheimer, J. 1994. "The False Promise of International Institutions, International Security 19 (3): 5-49.

[18] Andreev, A. 2007. "To What Extent Are International Organizations (IOs) Autonomous Actors in World Politics?" Opticon 1826 (2): 1-8.

[19] Thakur, R., and Weiss, T. G. 2009. "United Nations 'Policy': An Argument with Three Illustrations." International Studies Perspectives 10 (1): 18-35.

[20] Mitchell, S. 2006. "Cooperation in World Politics: the Constraining and Constitutive Effects of International Organisations." Iowa Research Online, Department of Political Science Publications: 1-32.

[21] Keohane, R. O. 1988. "International Institutions: Two Approaches.” International Studies Quarterly 32 (4): 379-96.

[22] Simon, H. A. 1957. Administrative Behavior: A Study of Decision-Making Processes in Administrative Organization (2nd ed.), New York: Macmillan.

[23] Davis, L. E., and North, D. C. 1971. Institutional Change and American Economic Growth. London: Cambridge University Press.

[24] Montpetit, E. 2012. "Policy (Program) Analysis and Policy Analysis Framework." Encyclopaedic Dictionary of Public Administration. http://www.dictionnaire.enap.ca.

[25] Dukeshire, S., and Thurlow, J. 2002. "A Brief Guide to Understanding Policy Development." Rural Communities Impacting Policy Project 1-16.

[26] Bogason, P., 2004. "Networks in Policy Analysis-Towards a New Pragmatism." Working Paper Series, Centre for Democratic Governance.

[27] Rao, R. M. V. 1986. Introduction of Public Policy Formulation: A Case Study of the National Policy of Education. http:/hdl.handle.net/10603/1918/pdf, 2011: $1-24$.

[28] Dye, T. R. 1969. "Income Inequality and American State Politics." American Political Science Review 63 (1): 
$157-62$.

[29] Turnbull, N., and Harold, L. 2008: "Problem Orientation' for Policy Sciences." Critical Policy Studies 2 (1): 72-91.

[30] Bobrow, D. B., Eulau, H., Landau, M., Jones, C. O., and Axelrod, R. 1977. "The Place for Police Analysis in Political Science: Five Perspectives." American Journal of Political Science 21 (2): 415-33.

[31] Easterly, W. 1994. "Explaining Miracles: Growth Regressions Meet the Gang of Four." Presented at NBER-East Asia Seminar on Economics.

[32] Van Donge, J. K., Henley, D., and Lewis, P. 2012. "Tracking Development in South East Asia and Sub-Saharan Africa." Development Policy Review 30: $1-17$.

[33] Booth, A. 1998. "Initial Conditions and Miraculous Growth: Why is South East Asia Different from Taiwan and South Korea?" SOAS, Department of Economics, University of London: 1-53.

[34] Loof, H. 2005, “The Asian Tigers': Course Macroeconomics-1N1703.” 2nd period, http://www.thepdfportal.com/wp11_38114.pdf.

[35] Roemer, M. 1996. "Could Asian Policies Propel African growth?" Harvard Institute of International Development, $1-30$.
[36] Young, A. 1995. "The Tyranny of Numbers: Confronting the Statistical Realities of the East Asian Growth Experience." The Quarterly Journal of Economics 110 (3): 641-80.

[37] Oberst, U. 2010. Third Tracking Development Conference, 11-15 May 2010, Asia-Europe Institute, University of Malaya, Putrajaya, Malaysia.

[38] Sachs, J. D. 2003. "Institutions Matter, but Not for Everything: The Role of Geography and Resources Endowments in Development Shouldn't Be under Estimated." Finance and Development 40 (2): 38-41.

[39] Henley, D., and Van Donge, J. K. 2012. "Policy for Development in Africa: Learning from Southeast Asia, Developmental Regimes in Africa." Policy Brief 1: 1-4.

[40] Bardhan, P. 2005. "Institutions Matter but Which Ones?" Economics of Transition 13 (3): 499-532.

[41] The National Committee of Inquiry into Education. "The Asian Tiger Economies: The role of and background to higher education in the Asian tiger economies." Section 9, Appendix http://www.leeds.ac.uk/educol/ncihe/app5.htm.

[42] Lasswell, H. D., and Kaplan, A. 1950. Power and Society: A Framework of Political Enquiry, New Haven Yale University Press. 